\title{
Keynote Speech at CPDP2016 on Technological, Totalitarianism, Politics and Democracy
}

\author{
Martin Schulz*
}

Ladies and Gentlemen,

We are living in the middle of a revolution. It is a revolution without banners, guns or a guillotine. But it is still a revolution turning the world upside down and leading us to question established certainties. As with every revolution, we do not know yet if it will work out for the better or for the worse. Both outcomes are possible: it is possible that in an on-line world more people will have access to knowledge, to innovative ideas and to global prosperity; that we will learn to understand one another better and to make ourselves understood better. But it is also possible that we will turn into remote-controlled 'data cows' who live in a world ruled over by a handful of multinational companies.

The title you gave me for my talk - 'Technological Totalitarianism, Politics and Democracy ${ }^{\prime}$ - hints at both outcomes. Both developments are possible. But I believe that the future will not be black and white. I believe the future will be grey. In other words: we will get a combination of both worlds.

Ladies and Gentlemen,

It should not come as news to anyone that a technological revolution always has major social implications. The industrial revolution which unfolded in the 18th and 19th centuries brought with it massive change: social and economic, political and cultural, urban and climatic. In its wake, new political movements took shape. These political movements drew attention to the social issues of the time and in the process gave our societies a democratic basis. In the longer term, technological progress went hand in hand with social progress. I am convinced that for a new technology to be both sustainable and successful it must contribute to social progress.

But what if we apply this analysis to a technological innovation which casts itself as a wrecking ball; a technological innovation whose aim is not just to play with the way society is organised, but instead to demolish the existing order and build something new in its place? The answer is that we are no longer talking about a process of technological or economic change. We are talking about a process which will change whole societies, indeed change the way we live in the future.

\footnotetext{
Martin Schulz is the President of the European Parliament. The speech was delivered on 28 January 2016 at the $9^{\text {th }}$ international conference Computers, Privacy and Data Protection 2016 (CPDP2016) in Brussels, Belgium. The text of the speech is also available at <http:// bit.ly/1KfEXUr> accessed 9 March 2016.
} 
Digitisation and Big Data are ushering in a new era in economics, in social relations, in data protection, in the media and the arts, in science and medicine, in the world of transport, in national security and in foreign policy. Politically, this means that the internet is no longer something which can be considered in isolation. From now on, every 'internet issue' will also be a social issue. For that reason, we cannot leave this to the nerds. It is a debate in which all sections of civil society must have their say.

Ladies and Gentlemen,

Many possible dangers or undesirable developments have already been flagged up not least by many of the people present here today. They, as experts, have a major voice in the debate: to give just one example, in her important contributions Professor Zuboff has referred to data mining as 'expropriation'. In view of the concentration of economic power in the hands of a few internet giants, she has warned about a return to the 'absolutism of the pre-modern era'. Professor Zuboff is surely right to do so. If it is true that personal data is the most important commodity of the 21 st century, then it is the task of politicians and the courts to enforce individuals' rights of ownership over their own data. Especially against those who, so far, have been clever enough to get their hands on this commodity without paying anything.

Facebook, Google, Alibaba, Amazon: these companies must not be allowed to shape the new world order. They have no mandate to do so! It is and must remain the proper task of the democratically elected representatives of the people to agree on rules and enshrine them in laws. Anyone who disagrees with the decisions taken by the regulators can seek to have them overturned by political means, through the efforts of civil society. We call this process democracy. And in our society there is the consensus that this is the way to take decisions which apply to everyone. I hope that this consensus will hold, despite - or perhaps because of - the enormous challenges facing us. I am a fervent advocate of the primacy of the democratic state. In Europe we are trying to go one better: by building a transnational democracy - the European Union. We are creating a new political entity to enable us Europeans to work together to address the global challenges; global challenges which are already today too great for individual nation states to cope with on their own.Ladies and Gentlemen,

Having said all that, I am not naive. All questions which have a bearing on regulation in the digital age are questions of power. There is much at stake: huge amounts of money, the power to impose standards and procedures, the ability to safeguard pluralism, alternative ways of thinking and personal autonomy.

In this speech I would like to put forward my objectives for discussion and emphasise a few points which are important to me. I am also keen to make our sense of European identity part of a debate which is inherently global in nature.I say that because I am sure that there are specifically European ways of looking at certain issues. I am not suggesting that our approach is necessarily better or worse. But our approach is based on our experiences. For example on the fact that we want to safeguard cultural diversity on our continent. Even though, at the same time, we have drawn up a dense frame- 
work of binding rules to govern dealings between the countries on our continent. But the many moves made towards greater Europeanisation in recent decades have not been accompanied by a process of cultural uniformisation. Indeed, I regard this as fundamental to public acceptance of the EU. Just look at the massive outcry when people fear that their country is sacrificing even a part of its cultural identity.

As you all know very well, data protection is a hugely sensitive issue in Europe. The revelations by Edward Snowden and others, the close links between intelligence services and major internet firms and businesses' insatiable appetite for information about every single aspect of our lives point to unwelcome developments in the on-line world. Developments which - if we were simply to accept them - could indeed give rise to a new totalitarianism. The internet lost its innocence long ago - the people who wield power over the internet are no longer the creative types, modern-day hippies searching for a better world in California.

Of course, our aim must still be to ensure that future generations continue to enjoy freedom, equality and a sense of community. I want us to go on living in a just society, a society based on solidarity and committed to peace. In that connection, digitisation and technological innovations offer many new opportunities, but those opportunities come with conditions. A 'natural order' will not emerge spontaneously, and anyone who claims otherwise is either naive or motivated by self-interest. All too often, those who shout 'freedom' or 'no regulation' the loudest are those who are keenest to safeguard their massive profits and their power. It is well worth remembering that by deregulating the financial sector we created a monster; a monster which on several occasions brought the world to the edge of disaster.

The task of politicians and civil society is to ensure that not just the happy few benefit from the digital revolution, but that as many people as possible benefit. In the midst of all this innovation, we also must ensure that those who want no part of this brave new world, those who want - as far as possible - to stay off-grid, are also protected.

To achieve these objectives:

We need, firstly, a consensus on what is and what is not allowed. I am not talking about net etiquette, about how to behave on-line. No, I am talking about a Charter of Fundamental Rights for the digital age. Given the revolutionary nature of the changes now taking place, I believe that we need the reassurance which such a document can bring. I also believe that the process of drawing up a Charter will already serve to clarify many issues - including those issues on which there is disagreement.

Secondly, we need to emphasise the importance of data protection and data security. For sure, there is no better day do this than today - on Data Protection Day.In this context, the agreement reached between the European Parliament and the Member States on the data protection package is a major step in the right direction. To those who claim that excessive levels of data protection would harm our economy and our businesses, I should like to say the following: in future, businesses, and private individu- 
als as well, will prefer to choose as the location for their data servers a place with high levels of data protection and data security guaranteed by an effective legal system. Data protection can become a significant location factor. Europe would do well to lay down strict standards; standards which must be observed by everyone who wants to trade with us. The judgment handed down by the European Court of Justice on the Safe Harbour Agreement sent out a warning. With luck it will provide the impetus needed to secure the right kind of agreement on data protection in the negotiations between Europe and the USA.

Thirdly, if the principle which supposedly underpins the internet economy - 'the winner takes it all' - were in fact to become its driving force, it would sound the death knell for innovation. Cartels and monopolies are just as damaging in the digital as in the analogue world. It must be possible for every idea and every standard to be challenged by a better idea or a better standard. And politicians must guarantee this. If we fail, our entire economic system - the free market economy - will be a thing of the past. Any time a monopoly is emerging we must be watchful. And we must use our cartel authorities and our competition law to ensure that pluralism and diversity are not threatened.

Fourthly, we must ensure that creativity is properly paid. In the 'copy and paste' era people must understand that creative thinking and intellectual property, is the basis for wealth generation. The creative act, the creation of web content, must generate a return for creators. Otherwise, creators and our society as a whole will be much worse off. This means, for example, that we need to clarify the relationship between creators, publishers and digital platforms. It is unacceptable that publishing houses should bear the cost of producing journalistic content which platforms can then simply reuse free of charge. After all, these platforms are not charitable institutions which work on a voluntary basis for the benefit of humanity. They are firms whose turnover and profits run into the billions. And they often use the intellectual property of others to generate that turnover and those profits. It is important to bear this in mind.

Ladies and Gentlemen,

One of the key questions for the coming years is: how can we ensure that digitisation benefits as many people as possible? How can we ensure that digitisation triggers a creative explosion which leads to more freedom, more participation, more security, more prosperity and more justice? We need to talk about this, but above all we need to act, because the fight for a fair and just society for the future starts now.

Thank you for your attention. 